\title{
Analisis Yuridis Putusan No.316/Pdt.G/2016/Pa.Krw tentang Aset Wakaf yang Diperjual Belikan menurut Hukum Islam dan UU No. 41 Tahun 2004 tentang Wakaf
}

\author{
Naila Salsabila*, M. Abdurrahman \\ Bandung, Indonesia. \\ *nailsa.salsabila@gmail.com, M.abdurrahman@gmail.com
}

Prodi Hukum Keluarga Islam, Fakultas Syariah, Universitas Islam

\begin{abstract}
Waqf is a solution offered by Islam which is expected to realize social welfare. Waqf is also a way to take advantage of assets that is highly recommended by Islam because waqf has the virtue of reward that does not falter even if the person who makes the waqf dies. Prior to the emergence of Law number 41 of 2004 concerning waqf, there were many problems with waqf property rights involving the heirs of Wakif and Nazir because the practice of waqf was not registered or registered. The research objectives of this thesis include: To examine the legal status of waqf land which is not registered according to Islamic law and the Constitution No. 41 of 2004 Concerning Waqf. And to review the decision Number 316/Pdt.G/2016/PA. Krw regarding the sale and purchase of waqf assets according. This study uses a normative juridical approach. Islamic law does not allow buying and selling of waqf assets, but if the waqf property is no longer usable or cannot be used properly, the waqf property can be sold and the proceeds from the sale of waqf assets can be used for the benefit of Muslims.
\end{abstract}

Keywords: Waqf, Pledge, Islamic Law.

Abstrak. Wakaf merupakan solusi yang ditawarkan oleh Islam yang diharapkan dapat mewujudkan kesejahteraan sosial. Wakaf juga merupakan suatu cara untuk memanfaatkan harta yang sangat dianjurkan oleh Islam karena wakaf mempunyai keutamaan pahala yang tidak putus-putus walaupun orang yang mewakafkan meninggal dunia. Sebelum munculnya Undang-Undang Nomor 41 Tahun 2004 tentang Wakaf, banyak problematika perwakafan tanah hak milik yang melibatkan ahli waris Wakif dengan Nazir karena praktik wakafnya tidak didaftarkan atau dicatatkan. Tujuan penelitian ini antara lain: Untuk mengkaji kedudukan status hukum tanah wakaf yang tidak tercatat menurut hukum Islam dan Undang-Undang Dasar No. 41 Tahun 2004 tentang Wakaf. Dan untuk mengkaji putusan Nomor 316/Pdt.G/2016/PA.Krw tentang jual beli aset wakaf. Penelitian ini mengunakan pendekatan yuridis normatif. Hukum Islam tidak membolehkan melakukan jual beli aset wakaf, akan tetapi apabila harta benda wakaf tersebut tidak lagi dapat digunakan atau tidak dapat dimanfaatkan sebagaimana mestinya maka harta benda wakaf tersebut dapat dijual dan hasil dari penjualan harta beda wakaf dapat digunakan untuk kepentingan umat Islam.

Kata Kunci: Wakaf, Ikrar, Hukum Islam. 


\section{A. Pendahuluan}

"Wakaf merupakan salah satu tuntunan ajaran Islam yang menyangkut kehidupan bermasyarakat dalam rangka ibadah ijtima'iyah (ibadah sosial). Karena wakaf adalah ibadah, maka tujuan utamanya adalah mengabdikan kepada Allah SWT. Dan ikhlas mencari RidhaNya". Wakaf adalah menahan harta baik secara abadi maupun sementara, untuk dimanfaatkan langsung atau tidak langsung, dan diambil manfaat hasilnya secara berulang-ulang di jalan kebaikan umum maupun khusus.

Wakaf menurut mayoritas ulama adalah menahan harta yang bisa dimanfaatkan, sementara barang tersebut masih utuh, dengan menghentikan sama sekali pengawasan terhadap barang tersebut dari orang yang mewakafkannya, untuk pengelolaan yang diperbolehkan dan riil, atau pengelolaan penghasilan barang tersebut untuk tujuan kebajikan dan kebaikan demi mendekatkan diri kepada Allah. Atas dasar ini, harta tersebut lepas dari kepemilikan orang yang mewakafkan dan menjadi tertahan dengan dihukum milik Allah. Orang yang mewakafkan terhalang untuk mengelolanya, penghasilan dari barang tersebut harus disedekahkan sesuai dengan tujuan perwakafan tersebut.

Mereka mendasarkan pendapat mereka pada surat Ali-Imran ayat 92 yang berbunyi:

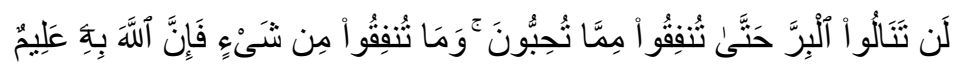

"Kamu sekali-kali tidak sampai kepada kebajikan (yang sempurna), sebelum kamu menafkahkan sehahagian harta yang kamu cintai. Dan apa saja yang kamu nafkahkan maka sesungguhnya Allah mengetahuinya."

"Salah satu alasan pembentukan Undang-Undang Nomor 41 Tahun 2004 tentang Wakaf adalah wakaf yang ada di masyarakat belum sepenuhnya berjalan tertib dan efisien, salah satu buktinya adalah di antara harta benda wakaf tidak terpelihara dengan baik, terlantar, bahkan beralih ke tangan pihak ketiga dengan secara melawan hukum". Di samping itu, karena tidak adanya ketertiban pendataan, banyak benda wakaf yang karena tidak diketahui datanya, jadi tidak terurus bahkan wakaf masuk dalam siklus perdagangan. Keadaan demikian itu tidak selaras dengan maksud dari tujuan wakaf yang sesunggguhnya dan juga akan mengakibatkan kesan kurang baik terhadap Islam sebagai akses penyelewengan wakaf, sebab tidak jarang sengketa wakaf terpaksa harus diselesaikan di pengadilan.

Sebelum munculnya Undang-Undang nomor 41 Tahun 2004 tentang Wakaf, banyak problematika perwakafan tanah hak milik yang melibatkan ahli waris Wakif dengan Nazir karena praktik wakafnya tidak didaftarkan atau dicatatkan. Tata cara wakaf tanah melalui proses ikrar wakaf.

Ikrar wakaf merupakan kehendak Wakif yang dilaksanakan oleh Wakif kepada Nadzir di hadapan PPAIW (Pejabat Pembuat Akta Ikrar Wakaf) dengan disaksikan oleh 2 (dua) orang saksi. PPAIW yang dimaksud adalah KUA. Setelah melakukan ikrar wakaf, petugas PPAIW akan menerbitkan Akta Ikrar Wakaf (AIW) yang digunakan untuk proses pendaftaran sertifikat tanah wakaf di Badan Pertanahan Nasional (BPN).

Pada tahun 1999, Ir. Suchron Anwar (Alm.) mewakafkan sebidang tanah seluas 29.000-meter persegi untuk diwakafkan dengan Nazir PP PERSIS. Kemudian PP Persis telah membuat Akta Ikrar Wakaf tersebut di Kantor Urusan Agama Kecamatan Karawang Barat dengan Nomor K01/W1/372/Tahun 1999 tanggal 24 Maret. Namun, Anak dari wakif tersebut yang berinisial ZK telah diketahui menjual tanah tersebut kepada pihak ketiga.

Akhirnya PP PERSIS mengajukan gugatan kepada Pengadilan Agama Karawang untuk menyelesaikan kasus perkara ini. Namun Pengadilan Agama Karawang mengabulkan eksepsi dari tergugat dan menolak gugatan dari penggugat karena merasa kasus ini adalah sengketa kepemilikan, bukan sengketa wakaf. Sedangkan dalam pembuktian terdapat bukti berupa dokumen Akta Ikrar Wakaf Nomor K01/W1/372/Tahun 1999 tanggal 24 Maret. Akta ini dikeluarkan oleh Kantor Urusan Agama Kecamatan Karawang Barat. Dengan adanya bukti Akta Ikrar Wakaf, sudah masuk kedalam perkara wakaf. Namun pihak Pengadilan Agama malah menolak gugatan tersebut. 


\section{B. Metodologi Penelitian}

\section{Jenis Data Penelitian}

Penelitian ini mengunakan jenis riset kepustakaan (library research) dan data lapangan. Riset kepustakaan (library research) adalah kegiatan yang berkenaan dengan metode pengumpulan data yang dilakukan dengan membaca dan mencatat buku-buku, literatur, dan sumber data lainnya. Dalam penelitian ini data yang diperoleh peneliti adalah Salinan putusan Nomor 0316/Pdt.G.2016/PA. Krw Pengadilan Agama Karawang. Sedangkan data lapangan penyusun peroleh dari objek penelitian secara langsung yaitu dengan cara peneliti melakukan wawancara dengan hakim yang memutus dan memeriksa perkara sengketa wakaf dalam hal ini putusan Nomor 0316/Pdt.G.2016/PA. Krw serta pihak-pihak terkait yakni Nadzir Wakif, dan pihak-pihak yang bersengketa.

\section{Sumber Data Penelitian}

Sumber data yang digunakan dalam penelitian ini adalah data primer dan data sekunder.

1.Data Primer

Data primer merupakan data yang dikumpulkan dalam melakukan penelitian lapangan dengan teknik atau pedoman wawancara yang dilakukan secara sitematis dan didasarkan pada tujuan penelitian dengan berpedoman pada panduan wawancara.

Dalam melakukan wawancara ini penyusun mempersiapkan terlebih dahulu pertanyaan-pertanyaan yang akan diajukan melalui interview guide (pedoman wawancara). Adapun yang menjadi narasumber wawancara adalah hakim yang memutuskan perkara sengketa wakaf putusan Nomor 0316/Pdt.G.2016/PA. Krw dan para pihak terkait yakni Nadzir Wakif, dan pihak-pihak yang bersengketa.

2.Data Sekunder

Data sekunder diperoleh atau dikumpulkan dari sumber-sumber yang telah ada. Data sekunder diperoleh dengan penelitian kepustakaan guna mendapatkan landasanlandasan teoritis berupa pendapat atau tulisan para ahli atau pihak lain yang berwenang. Data sekunder dalam penelitian ini penyusun peroleh dari: UndangUndang Nomor 41 Tahun 2004 dan Kompilasi Hukum Islam.

\section{Teknik Pengumpulan Data}

Teknik pengumpulan data dalam penelitian ini adalah sebagai berikut:

1.Studi Pustaka

Studi pustaka yaitu teknik pengumpulan data dengan mengadakan studi penelaahan terhadap buku-buku, literatur, laporan, catatan, dokumentasi yang berkaitan dengan masalah yang akan diteliti.

Dalam penelitian ini penyusun melakukan studi pustaka dengan cara mempelajari salinan putusan Nomor 0316/Pdt.G.2016/PA. Krw.

2.Wawancara

Wawancara merupakan teknik pengumpulan data melalui tanya jawab secara lisan yang berlangsung satu arah dengan tujuan mendapatkan jawaban dari permasalahan yang diteliti.

Dalam hal ini penyusun melakukan wawancara dengan subyek penelitian hakim Pengadilan Agama Karawang yang memutus dan memeriksa sengketa wakaf putusan Nomor 0316/Pdt.G.2016/PA. Krw, Nadzir Wakif, dan pihak-pihak yang bersengketa.

\section{Teknik Analisis Data}

Teknik analisis data merupakan salah satu cara yang digunakan untuk menganalisis, mempelajari serta mengolah data, sehingga dapat diambil kesimpulan yang kongkrit tentang permasalahan yang diteliti. Analisis data yang digunakan dalam penelitian ini adalah analisis data kualitatif, yaitu analisis data yang mengungkapkan dan mengambil kebenaran yang diperoleh dari kepustakaan yang meliputi yurisprudensi, literatur dan ketentuan yang ada dan 
berkaitan dengan permasalahan sengketa wakaf.

Metode yang digunakan untuk menganalisis data adalah metode induktif dan deduktif. Metode induktif yaitu suatu pembahasan yang dimulai dari fakta yang ada bersifat khusus dan kongkrit kemudian menuju kepada generalisasi yang bersifat umum. Deduktif, yaitu penarikan kesimpulan yang berasal dari pengetahuan umum tersebut, hendak dinilai satu tujuan khusus.

\section{Hasil Penelitian dan Pembahasan}

Praktek wakaf di Indonesia sudah terjadi sebelum Indonesia merdeka. Masyarakat muslim Indonesia melakukan praktek wakaf baik bersifat perseorangan maupun kelompok. Tujuan wakaf adalah memanfaatkan harta benda wakaf sesuai dengan fungsinya. Wakaf berfungsi mewujudkan potensi dan manfaat ekonomis harta benda wakaf untuk kepentingan ibadah dan untuk memajukan kesejahteraan umum. Keberadaan wakaf hingga saat ini dirasakan sangat bermanfaat bagi masyarakat muslim Indonesia.

Pelaksanaan wakaf sebelum adanya Undang-Undang yang mengatur tentang wakaf. Masyarakat muslim Indonesia melaksanakan wakaf mengunakan kebiasaan keagamaan, seperti melaksanakan wakaf secara lisan atau atas dasar saling percaya kepada seseorang atapun kepada lembaga tertentu yang diberi kepercayaan. Pelaksaan wakaf pada saat itu dilaksanakan tanpa melalui prosedur administratif seperti melakukan pencatatan wakaf hal ini karena masyarakat muslim memandang wakaf sebagai amal shaleh dan harta wakaf hanya milik oleh sehingga tidak ada yang berani untuk mengangu gugat harta yang telah diwakafkan.

Setelah dikaji sumber hukum Islam Al-Quran maupun Hadits, masih belum ditemukan aturan yang mengharuskan adanya pencatatan wakaf sebagaimana yang terdapat dalam Undang-Undang Perwakafan jo. KHI maupun aturan dibawahnya.

Tujuan pokok hukum Islam adalah merealisasikan kemaslahatan. Tidak semua persoalan umat disebutkan secara tegas hukumnya atau dalilnya dalam Al-Quran dan Hadits, hal-hal yang tidak disebutkan secara tegas dalam Al-Quran dan Hadits dapat diselesaikan melalui qiyas. Banyak persoalan baru yang tidak ada dalilnya dalam Al-Quran dan Hadits, sehingga harus diselesaikan dengan metode lain seperti Maslahah Al-Mursalaat. Ketentuan dari Maslahah Al-Mursalaat yaitu tidak boleh bertentangan dengan tujuan-tujuan syariat (Maqashid As-Syari'ah). Sesuai dengan syarat tersebut maka maslahah harus sesuai dengan dalil yang qath'i.

Adapun manfaat dari Mashlahah Mursalah adalah suatu mashlahah yang sesuai dengan tujuan, prinsip dan dalil-dalil syara' yang berfungsi untuk menghilangkan kesempitan, baik yang bersifat primer maupun sekunder.

Dengan demikian pencatatan wakaf merupakan implementasi dari hasil ijtihad para ulama dengan metode Mashlahah Mursalah sebagai wujud nyata dari maqasidul syariah yaitu diantaranya Hifz Din (menjaga agama), dan Hifz Mall (menjaga Harta). Tetapi penggunaan mashlahah mursalah tidak boleh bertentangan dengan hukum yang telah ditetapkan oleh nash alquran dan hadits. Seperti halnya dalam hukum perkawinan, perkawinan dapat dikatakan sah apabila telah terpenuhi rukun dan syarat perkawinan walaupun dapat dikatakan perkawinan tersebut tidak tercatat. Akibat dari tidak tercatatnya perkawinan tidak dapat serta merta mengatakan bahwa perkawinan tersebut tidak sah, karena pencatatan perkawinan hanyalah suatu produk ijtihad. Tidak terkecuali dengan hukum perwakafan, tidak dapat dikatakan bahwa tanah wakaf tersebut tidak sah walaupun tanah tersebut tidak tercatat di KUA/BWI sebagai PPAIW hanya saja sulit untuk membuktikan ketika adanya suatu permasalahan dikemudian hari jika tanah tersebut tidak dicatat.

Setelah Indonesia merdeka pemerintah membentuk Undang-Undang yang mengatur tentang wakaf. Pada awalnya pemerintah membentuk Undang-Undang Nomor 5 Tahun 1960 tentang Peraturan Dasar Pokok-Pokok Agraria pada Pasal 499 ayat (3) menjelaskan tentang melindungi keberlangsungan perwakafan tanah, pemerintah dan memberikan peraturan melalui Peraturan Pemerintah Nomor 28 Tahun 1977 tentang Perwakafan dan Tanah Milik.

Seiring kemajuan zaman dan banyaknya sengeketa wakaf yang terjadi di Pengadilan Agama dan hakim dalam memutuskan perkara khususnya wakaf atantara Pengadilan Agama yang satu dengan Pengadilan Agama yang lain berbeda hal ini menimbulkan ketidak pastian 
hukum maka pemerintah Indonesia menuyusun Kompilasi Hukum Islam (KHI) dimana KHI ini dijadikan pedoman oleh para hakim di lingkungan Pengadilan Agama dalam memutuskan yang menjadi kewenangan Pengadilan Agama.

Namun dalam perkembangannya peraturan-peraturan yang sudah ada masih sebatas wakaf yang bersifat benda tidak bergerak, sehingga dirasa masih belum lengkap sehingga lahirlah Undang-Undang Nomor 41 Tahun 2004 tentang wakaf. Hingga saat ini pedoman wakaf yang dipakai dalam hukum di Indonesia adalah Kompilasi Hukum Islam (KHI) dan Undang-Undang Nomor 41 Tahun 2004 tentang Wakaf.

Berdasarkan ketentuan Pasal 17 Undang-Undang No.41 Tahun 2004 tentang Wakaf dapat disimpulkan bahwa pelaksanaan wakaf sah apabila wakaf tersebut dilaksanakan oleh wakif kepada nadzir di hadapan PPAIW dan disaksikan dua orang saksi. Nadzhir wajib mencatatkan iqrar wakaf maximal 7 hari setelah ikrar wakaf dilaksanakan.

Berdasarkan uraian diatas menurut hukum Islam dan No.41 Tahun 2004 tentang wakaf, wakaf sah apabila dilaksanakan sesuai dengan tata cara menurut Kompilasi Hukum Islam (KHI) dan No.41 Tahun 2004 tentang Wakaf. Kedudukan wakaf yang belum dicatat sah menurut hukum Islam tetapi belum sah menurut hukum negara karena wakaf tersebut telah dilaksanakan sesuai dengan ketentuan hukum Islam, dan wakaf yang belum dicatat tidak memiliki kekuatan hukum, maka wakaf yang terjadi sebelum diundangkannya UndangUndang No.41 Tahun 2004 tentang Wakaf. Wajib dilaporkan kepada Kantor Urusan Agama di wilayah mana harta benda wakaf itu diwakafkan. Kedudukan wakaf yang sah apabila wakaf tersebut dicatatakan dan memiliki bukti sertifikat wakaf. Pencatatan wakaf dan sertifikat wakaf menjadi penting hal ini disebabkan apabila dikemudian hari terjadi sengketa wakaf maka wakaf memiliki bukti otentik.

\section{Duduk Perkara Nomor 316/Pdt.G/2016/PA.Krw}

Perkara Nomor 316/Pdr.G/2016/PA.Krw berisi tentang sengketa wakaf. Perkara tersebut menjelaskan tidak dikabulkannya gugatan penggugat. Penggugat adalah Ketua Umum Pimpinan Pusat Persatuan Islam (PP PERSIS) masa jihad 2015-2020. Alasan PP Persis mengajukan gugatan ke Pengadilan Agama Karawang sehubungan dengan tanah yang diwakafkan oleh alm. Ir. Suchron Anwar yang terletak di Ds. Karangpawitan Kec. Karawang dengan luas $29.000 \mathrm{~m}^{\wedge} 2$ dengan akta Ikrar Wakaf Nomor : K01/W1/372/Tahun 1999.

Pada tahun 2006, Ahmad Fauzi sebagai salah satu pengurus Pimpinan Daerah Karawang memberitahukan kepada pihak PP Persis bahwa tanah wakaf yang terletak di Karawang tersebut akan terkena pembangunan jalan lingkar karawang. Kemudian PP Persis memberikan Sertifikat Hak Milik tanah tersebut a.n Ir. Suchron Anwar berikut dengan akta Ikrar Wakaf, kemudian PP Persis memerintahkan kepada PD Karawang untuk menyelesaikan administrasi tanah wakaf tersebut untuk dijadikan Sertifikat Wakaf.

Namun pada Tahun 2012 PP Persis mendapatkan informasi bahwa objek wakaf tersebut telah dijual belikan oleh ZK Ahli Waris dari alm. Ir. Suchron Anwar kepada pihak ketiga.

Kuasa Hukum Tergugat I yaitu ZK dan Pihak Ketiga selaku pembeli melayangkan eksepsi ke Pengadilan Agama Karawang bahwa perkara aquo, merupakan sengketa kepemilikan sehingga yang berwenang memeriksa, memutus, dan menyelesaikan perkara aquo adalah Pengadilan Negeri.

Kemudian Hakim Pengadilan Agama Karawang mengabulkan eksepsi Tergugat serta menolak gugatan Penggugat.

\section{Analisis}

Secara bahasa jual beli berarti memindahkan hak milik terhadap benda dengan akad saling mengganti, sedangkan menurut istilah berarti menjual, mengganti dan menukar sesuatu dengan sesuatu yang lain. Menurut istilah terminologi yang dimaksud jual beli adalah sebagai berikut:

1. Menukar barang dengan barang atau dengan cara melepaskan hak milik dari orang yang satu kepada orang yang lain atas dasar saling merelakan 
2. Pemilikan harta benda dengan cara sesuai dengan hukum syara

3. Saling menukar hara, saling menerima, dapat dikelola dengan ijab qabul dengan cara yang telah ditentukan oleh hukum syara

4. Tukar menukar benda dengan benda yang lain dengan cara khusus (diperbolehkan).

Menurut Ulama Mazhab Syafiiyah, ulama Syafiiyah berpendapat bahwa menjual harta benda wakaf dalam kondisi apapun tidak diperbolehkan termasuk menjual harta wakaf khusus seperti wakaf bagi keturunannya sendiri. Terhadap wakaf khusus seperti wakaf pohon yang sudah layu menurut ulama Syafiiyah berpendapat bahwa pohon tersebut boleh ditebang dan kayunya dapat dijadikan kayu bakar tetapi tidak diperbolehkan untuk dijual belikan.

Dari ketentuan Pasal 225 Ayat (1 dan 2) dapat disimpulkan bahwa harta benda yang telah diwakafkan tidak dapat dilakukan perubahan atau penggunaan lain dapat diartikan bahwa harta benda wakaf tidak dapat dijual belikan kecuali jika harta benda wakaf tersebut sudah tidak sesuai dengan tujuan wakaf ketika ikrar wakaf dilaksanakan karena kepentingan umum maka harta benda wakaf dapat dijual belikan dengan persetujuan Kepala Kantior Urusan Agama dimana ikrar wakaf tersebut dilaksanakan.

Mengenai jual beli asset wakaf menurut hukum Islam dapat disimpulkan bahwa pada dasarnya jual beli aset wakaf tidak diperbolehkan akan tetapi apabila asset wakaf tersebut sudah tidak lagi dapat digunakan sebagaimana mestinya atau sudah tidak lagi dapat dimanfaatkan kegunaan dari asset wakaf tersebut maka asset wakaf tersebut dapat dijual dengan tujuan uang dari penjualan asset wakaf tersebut dapat dialih fungsikan seperti membangun masjid, membangun sekolah atau kepetingan umat Islam lainnya.

Sedangkan berkaitan dengan Putusan Nomor 316/Pdt.G/2016/PA. Krw tentang penjualan objek wakaf. Penjualan aset wakaf tersebut dilakukan oleh Tergugat kepada Pihak ketiga hanya untuk kepentingan secara pribadi bukan atas dasar kepentingan umat ataupun hal yang diperbolehkan oleh Hukum Islam maupun Perundang-undangan.

Kemudian hakim menolak permohonan gugatan yang dilayangkan oleh Penggugat yaitu PP Persis dengan pertimbangan mengabulkan eksepsi Tergugat yang menyatakan perkara tersebut merupakan perkara sengketa kepemilikan, sehingga yang berhak menangani perkara ini adalah Pengadilan Negeri.

Hal itu tidak sependapat dengan penulis, penulis memandang yang pertama sengketa kepemilikan adalah perebutan objek oleh dua atau lebih yang saling mengklaim atas objek tersebut. Sedangkan dalam wakaf tidak ada yang memiliki tanah wakaf tersebut, dalam wakaf hanya ada istilah Nadzir yaitu orang/badan yang diberi amanah untuk mengelola tanah wakaf agar tanah wakaf tersebut menjadi produktif. Jadi secara sederhana status kepemilikan dari tanah wakaf bukanlah Nadzir.

Yang kedua, penulis berpandangan PP Persis telah mendalilkan dalam positanya mengenai status tanah tersebut yang memuat Akta Ikrar Wakaf dari KUA setempat dengan Nomor: K01/W1/372/Tahun 1999. Sehingga sangatlah jelas perkara tersebut merupakan kewenangan daripada Pengadilan Agama sesuai dengan Pasal 49 Undang-Undang No. 7 Tahun 1989 tentang Pengadilan Agama berikut dengan perubahannya.

\section{Kesimpulan}

Dari uraian di atas dapat diambil kesimpulan sebagai berikut:

1. Kedudukan ikrar wakaf yang tidak tercatat menurut hukum Islam wakaf tersebut sah. Sedangkan Undang-Undang Nomor 41 Tahun 2004 tentang Wakaf adalah wakaf tersebut tidak sah menurut hukum positif tetapi sah menurut hukum Islam atau agama. Ikrar wakaf yang tidak tercatat tidak berkuatan hukum.

2. Hukum Islam tidak membolehkan melakukan jual beli aset wakaf, akan tetapi apabila harta benda wakaf tersebut tidak lagi dapat digunakan atau tidak dapat dimanfaatkan sebagaima mestinya maka harta benda wakaf tersebut dapat dijual dan hasil dari penjualan harta beda wakaf dapat digunakan untuk kepentingan umat Islam seperti membangun masjid, membangun sekolahan, dan lain sebagainya. Berkaitan dengan Putusan Nomor 316Pdt.G/2016/PA.Krw tentang Jual Beli Aset Wakaf hukum Islam membolehkan menjual aset wakaf tersebut dikarenakan tidak adanya bukti yang jelas 
atau meyakinkan jika aset wakaf tersebut telah diwakafkan.

3. Pasal 40 dan 42 Undang-Undang Nomor 41 Tahun 2004 tentang Wakaf melarang menjual aset wakaf akan tetapi jika aset wakaf tersebut tidak dapat berfungsi lagi atau tidak dapat digunakan, dimanfaatkan maka aset wakaf tersebut dapat dijual dan hasil dari penjualan aset wakaf tersebut dapat digunakan untuk membangun masjid, sekolah atau kepentingan umat islam lainnya. mengenai Putusan Nomor 316Pdt.G/2016/PA.Krw tentang Jual Beli Aset Wakaf Undang-Undang Nomor 41 Tahun 2004 tentang Wakaf membolehkan menjual aset wakaf tersebut dikarenakan tidak adanya bukti yang jelas bahwa harta benda tersebut telah diwakafkan.

\section{Acknowledge}

Penulis mengucapkan terimakasih kepada Universitas Islam Bandung yang sudah memberikan kesempatan kepada saya untuk membuat jurnal ini.

Terimakasih juga tidak lupa saya ucapkan kepada Pengadilan Agama Karawang yang telah membantu saya dalam mengerjakan jurnal ini.

\section{Daftar Pustaka}

[1] Bakri, Asafri Jaya. (1996). Konsep Maqasid Syari'ah menurut al-Syatibi. Jakarta: PT Raja Grafindo Persada.

[2] GUMILAR, Agi Sukma. (2016). "Kerangka Teoritis Filosofis Wakaf Uang melalui Perbankan Syariah". Tahkim (Jurnal Peradaban dan Hukum Islam), Vol. 1 (2).

[3] HAMZANI, Achmad Irwan; MUKHIDIN, Mukhidin. (2016). "Perlindungan hukum terhadap harta benda wakaf sebagai aset publik di kecamatan Wiradesa kabupaten Pekalongan". Ijtihad: Jurnal Wacana Hukum Islam dan Kemanusiaan, Vol. 16 (2)

[4] HASTUTI, Qurratul Aini Wara. (2016). "Kewenangan Pengadilan Agama Kudus Dalam Penyelesaian Sengketa Wakaf". ZISWAF: Jurnal Zakat dan Wakaf. Vol. 1 (1).

[5] HAYATUDIN, Amrullah; IBRAHIM, Muhammad Andri; RAMADHANTY, Ghina Nabila. (2020). "Tinjauan Fikih Wakaf dan Undang-undang Nomor 41 Tahun 2004 Tentang Wakaf terhadap Pengelolaan Wakaf Uang oleh Yayasan Tenda Visi Indonesia". Tahkim (Jurnal Peradaban dan Hukum Islam), Vol. 3 (2)

[6] HENDI SUHENDI, Hendi. (2018). “Optimalisasi Aset Wakaf Sebagai Sumber Dana Pesantren Melalui Pelembagaan Wakaf (Studi Kasus Pelembagaan Wakaf Pesantren Baitul Hidayah)". Tahkim (Jurnal Peradaban dan Hukum Islam), Vol. 1 (1).

[7] IDRUS, Muammar Alay. (2017). "Keabsahan, Kepastian Hukum Dan Perlindungan Hukum Atas Perwakafan Yang Tidak Tercatat (Studi Kasus Praktek Perwakafan Tanah Di Kecamatan Sukamulia)". Jurnal IUS: Kajian Hukum dan Keadilan, Vol. 5 (1).

Ikhtiar Bani Van Hoev

[8] MALIK, Zaini Abdul, et al. (2020). "Analisis Fatwa (Mui) No: 106/dsn-mui/x/2016 Terhadap Implementasi Wakaf Asuransi Di Lembaga Prudential Indonesia”. Tahkim (Jurnal Peradaban dan Hukum Islam), Vol. 3 (1)

[9] Manan, Abdul. (2006). Aneka Masalah Hukum Perdata Islam di Indonesia. Jakarta : Kencana

[10] Manan, Bagir. (2006). Kata Pengantar Dalam Buku Abdul Manan Reformasi Hukum Islam. Jakarta: PT. Raja Grafindo Persada.

[11] Meliala, Djaja S. (2014). Hukum Perdata Dalam Perspektif BW. Bandung:

[12] Mubarok, Jaih. (2008). Wakaf Produktif. Bandung : Simbiosa Rekatama Media.

Nuansa Aulia

Prenamedia Group

[13] Rofiq, Ahmad. (1997). Hukum Islam di Indonesia. Jakarta: PT Raja Grafindo Persada.

[14] Rohman, Adi Nur. (2020). Hukum Wakaf Indonesia. Jakarta: Ubharajaya.

[15] Sabiq, Sayyid. (2004). Fikih Sunnah. Terj. Muhammad Nasiruddin Al-Allbani,, Jilid 5. 
82 | Naila Salsabila, et al.

Jakarta: Pustaka Azzam.

[16] Sarwat, Ahmad. (2018). Fiqih Wakaf. Jakarta: Rumah Fiqh Publishing

[17] SETIAWAN, bin Lahuri. (2018). "Analisis Kiasan Wakaf Terhadap Wakaf Jiwa Di Pondok Modern Darussalam Gontor". Jurnal of Indonesian Comparative of Law, Vol. $1(2)$

[18] Sulistiani, Siska Lis. (2018). "Perbandingan Sumber Hukum Islam."

Tahkim (Jurnal Peradaban dan Hukum Islam). Vol. 1 (1) 